\title{
Analysis of the Essential Oils of two Hypericum species ( $H$. Lanuginosum var. lanuginosum Lam. and $H$. perforatum L.) from Turkey
}

\section{Türkiye'de Yetişen İki Hypericum Türünün ( H. lanuginosum var. lanuginosum Lam. and H. perforatum L.) Uçucu Yağlarının analizi}

\author{
Research Article
}

\section{Ebru Yüce}

Pertek Sakine Genç Vocational School, Tunceli University, Tunceli, Turkey.

\section{A B S T R A C T}

T

he chemical composition of the essential oils of aerial parts of Hypericum lanuginosum var. lanuginosum Lam. and Hypericum perforatum L. were analyzed by GC and GC-MS. Forty one compounds were identified in the essential oils of $H$. lanuginosum with spathulenol (17.3\%), caryophyllene oxide (13.1\%), $\alpha$-pinene (11.7\%) and undecane $(6.2 \%)$ as main constituents. Forty components were identified in the oil of $H$. perforatum with $\beta$-selinene (19.4\%), bicyclogermacrene (15.3\%), 2 tetradecene (8.2\%) and $\alpha$-amorphene (8.1\%) as the most abundant components.

\section{Key Words}

Clusicaceae, Hypericum lanuginosum var. lanuginosum, Hypericum perforatum, spathulenol, $\beta$-selinene.

\section{ÖZET}

Lypericum lanuginosum var. lanuginosum Lam. ve Hypericum perforatum L. taksonlarının toprak üstü kısımlarının uçucu yağlarının kimyasal birleşimi GC ve GC-MS (Gaz kromatografisi-kütle spektrometresi) ile analiz edildi. H. lanuginosum'da 41 bileşen saptandı. Bu türde spathulenol (17.3\%), caryophyllene oxide (13.1\%), $\alpha$-pinene $(11.7 \%)$ ve undecane (6.2\%) major bileşenleri tespit edildi. $H$. perforatum taksonunda 40 bileşen tanımlandı. Bu bileşenlerden $\beta$-selinene (19.4\%), bicyclogermacrene (15.3\%), 2 tetradecene (8.2\%) ve $\alpha$-amorphene (8.1\%) en çok bulunan bileşenlerdir.

\section{Anahtar Kelimeler}

Clusicaceae, Hypericum lanuginosum var. lanuginosum, Hypericum perforatum, spathulenol, $\beta$-selinene.

Article History: Received: Dec 16, 2015; Revised: Mar 11, 2016; Accepted: Mar 11, 2016; Available Online: Apr 01, 2016. DOI: $10.15671 /$ HJBC.20164417564

Correspondence to: E. Yüce; Pertek Sakine Genç Vocational School, Tunceli University, Tunceli, Turkey. 


\section{INTRODUCTION}

The genus Hypericum belongs to the Clusicaceae and encompasses 460 species worldwide of which ca. 89 species are found in Turkey. Hypericum lanuginosum var. lanuginosum belongs to the Section Adenosepalum Spach and Hypericum perforatum to the Section Hypericum Robson in Flora of Turkey. Both taxa are black glands present on anters and intramarginally on leaves; seeds reticulate or foveolate to ribbed or rugulose. Hypericum lanuginosum var. lanuginosum has ovate to lanceolate or oblong and densely whitish-pubescent to scabrellous leaves. Hypericum perforatum has leaves narrowly ovate or lanceolate to elliptic-oblong or linear, sessile or subsessile, plane, and large pellucid dots. Hypericum lanuginosum var. lanuginosum differs from $H$. perforatum in having sepals broadly ovate to oblong or rarely lanceolate and usually obtuse to rounded [1].

Hypericum species have been reported to contain many bioactive compounds, namely naphthodianthrones, phloroglucinols, flavonoids, phenylpropanes, essential oils, amino acids, xanthones, tannins, procyanidins and other components, which possess a wide array of biological properties [2-4]. Major/high component of the Hypericum essential oils are 1-hexanal, $\alpha$-pinene, pinene, 3-methylnonane, 3-methyldecane, caryophyllene oxide spathulenol, germacrene $D$, camphor, limonene and trans-caryophyllene [5-9]. Variations in the essential oils composition of many species of this genus were previously reported, and depending on genetic and environmental factors, seasonal variation, plant organs and analytical methods used [10-12].

The flowering plant genus Hypericum (Hypericaceae) contains the well-known medicinally valuable species Hypericum perforatum (common St. John's wort). Species of Hypericum contain many bioactive constituents, including proanthocyanins, flavonoids, biflavonoids, xanthones, phenylpropanes and naphthodianthrones that are characterized by their relative hydrophilicity, as well as acylphloroglucinols and essential oil components that are more hydrophobic in nature [13].
In the present study, we report on the yield and chemical composition of the essential oil isolated from Hypericum lanuginosum var. lanuginosum and $H$. perforatum plants obtained from aerial parts. Although the composition of $H$. perforatum oil has been the subject of previous studies [14-16], to the best of our knowledge, there is no publication on the composition of $H$. lanuginosum var. lanuginosum essential oil.

The aims of this study are to determine distribution of the essential oil constituents in genus and compare them with the other Hypericum taxon.

\section{MATERIAL AND METHODS}

\section{Plant Material}

The specimens of $H$. lanuginosum var. lanuginosum and $H$. perforatum were collected Gaziantep and Tunceli (Turkey) in 2011. Voucher specimens (FUH-9664 and FUH-9675) are kept at the Firat University Herbarium (FUH), Elazig, Turkey.

\section{Isolation of the Essential Oils}

Air-dried aerial parts of the plant materials (100 g) were subjected to hydrodistillation using a Clevenger-type apparatus for $3 \mathrm{H}$.

\section{Gas Chromatographic (GC) Analysis}

The essential oil was analysed using HP 6890 GC equipped with FID detector and HP- 5 MS (30 m x $0.25 \mathrm{~mm}$ i.d., film tickness $0.25 \mu \mathrm{m}$ ) capillary column was used. The column and analysis conditions were the same as in GC-MS expressed as below. The percentage composition of the essential oils was computed from GC-FID peak areas without correction factors.

\section{Gas Chromatography/Mass Spectrometry (GC- MS) Analysis}

The oils were analyzed by GC-MS, using a Hewlett Packard system. HP- Agilent 5973 N GC-MS system with 6890 GC in Plant Products and Biotechnology Res. Lab. (BUBAL) in Firat University. HP-5 MS column (30 m×0.25 mm i.d., film tickness $0.25 \mu \mathrm{m}$ ) was used with helium as the carrier gas. Injector temperature was $2500 \mathrm{c}$, split flow was $1 \mathrm{ml} / \mathrm{min}$. The GC oven temperature was kept at $70^{\circ} \mathrm{C}$ for $2 \mathrm{~min}$. and programmed to 
Table 1. Constituents of the essential oils from Hypericum lanuginosum var. lanuginosum (a) and H. perforatum (b).

\begin{tabular}{|c|c|c|c|c|}
\hline \multirow{2}{*}{ Number } & \multirow{2}{*}{ Compounds } & \multirow{2}{*}{ RRI } & \multicolumn{2}{|c|}{$\%$ concentration } \\
\hline & & & a & $b$ \\
\hline 1 & Octane & 971 & - & 0.1 \\
\hline 2 & Nonane & 996 & 0.5 & - \\
\hline 3 & $\alpha$-pinene & 1021 & 11.7 & 0.4 \\
\hline 4 & Verbenene & 1037 & 0.1 & - \\
\hline 5 & Pinene & 1056 & 0.5 & - \\
\hline 6 & $\mathrm{p}$-Cymene & 1091 & 0.1 & - \\
\hline 7 & Limonene & 1095 & 0.1 & - \\
\hline 8 & 2-methyldecane & 1121 & - & 0.1 \\
\hline 9 & Undecane & 1147 & 6.2 & 0.7 \\
\hline 10 & Alloocimene & 1167 & 0.1 & - \\
\hline 11 & $\alpha$-Terpineol & 1215 & 0.4 & 0.2 \\
\hline 12 & $\begin{array}{c}\text { Bicyclo }(3,1,1) \text { hept-3-en-2- } \\
\text { one }\end{array}$ & 1223 & 0.3 & - \\
\hline 13 & Myrtenol & 1264 & - & 0.2 \\
\hline 14 & $\alpha$-Cubebene & 1360 & 0.4 & 0.2 \\
\hline 15 & Elemene & 1370 & 0.5 & 1.0 \\
\hline 16 & Caryophyllene & 1393 & 0.4 & 0.9 \\
\hline 17 & Cubebene & 1400 & 0.1 & 0.2 \\
\hline 18 & Aromadendrene & 1406 & 1.5 & 0.7 \\
\hline 19 & Trans Farnesene & 1415 & - & 1.3 \\
\hline 20 & $\alpha$-Humulene & 1418 & - & 0.3 \\
\hline 21 & Neo alloocimene & 1421 & 0.5 & 0.2 \\
\hline 22 & $\alpha$-Amorphene & 1430 & 1.9 & 8.1 \\
\hline 23 & Germacrene D & 1435 & 1.1 & 3.2 \\
\hline 24 & $\beta$-selinene & 1440 & 0.9 & 19.4 \\
\hline 25 & Valencene & 1442 & - & 0.5 \\
\hline 26 & Bicyclogermacrene & 1445 & - & 15.3 \\
\hline 27 & $\alpha$-Muurolene & 1446 & 0.4 & - \\
\hline 28 & Naphthalene & 1456 & 1.2 & 1.0 \\
\hline 29 & Cadinene & 1458 & - & 1.7 \\
\hline 30 & Cis-Calemenene & 1460 & - & 0.8 \\
\hline 31 & $\alpha$-Cadinene & 1470 & - & 0.2 \\
\hline 32 & Dodecanoic acid & 1484 & - & 1.1 \\
\hline 33 & Epiglobulol & 1486 & 0.7 & - \\
\hline 34 & cis-3-Hexenyl benzoate & 1490 & - & 0.4 \\
\hline
\end{tabular}


Table 1. Constituents of the essential oils from Hypericum lanuginosum var. lanuginosum (a) and $H$. perforatum (b), (continue).

\begin{tabular}{|c|c|c|c|c|}
\hline 35 & Spathulenol & 1495 & 17.3 & 3.9 \\
\hline 36 & Caryophyllene oxide & 1498 & 13.1 & - \\
\hline 37 & Azulene & 1500 & 3.8 & 0.4 \\
\hline 38 & Salvial-4(14)-en-1-one & 1505 & 2.7 & - \\
\hline 39 & Cyclododecane & 1511 & 0.9 & - \\
\hline 40 & Ledol & 1514 & 1.3 & 0.3 \\
\hline 41 & 1H-3a.7-Methanazulene & 1518 & - & 1.3 \\
\hline 42 & Copaene & 1528 & - & 2.6 \\
\hline 43 & Bicyclo $(4,4,0)$ dec-1-ene & 1532 & 1.2 & 1.2 \\
\hline 44 & Selinene & 1534 & 0.9 & - \\
\hline 45 & $\alpha-$ Cadinol & 1539 & 4.4 & 1.8 \\
\hline 46 & -Methanazulene & 1541 & - & 4.5 \\
\hline 47 & $\alpha$-Calacorene & 1544 & 0.5 & - \\
\hline 48 & Caryophyllene-II & 1548 & 1.3 & - \\
\hline 49 & 2 Tetradecene & 1550 & - & 8.2 \\
\hline 50 & 12-Norcyercene-B & 1558 & - & 1.4 \\
\hline 51 & Ledene oxide & 1574 & 0.3 & - \\
\hline 52 & 6-Isopropenyl-4 & 1576 & - & 0.6 \\
\hline 53 & $\alpha$-Cyperone & 1586 & - & 0.2 \\
\hline 54 & Benzilbenzoate & 1596 & 0.4 & 0.3 \\
\hline 55 & 2- Pentadecanone & 1631 & 1.2 & 0.3 \\
\hline 56 & $\begin{array}{l}\text { 1,2-Benzenedicarboxylic } \\
\text { acid }\end{array}$ & 1639 & 0.7 & - \\
\hline 57 & Cyclotetradecane & 1650 & - & 0.5 \\
\hline 58 & Pentacosane & 1671 & 1.4 & - \\
\hline 59 & Longipinocarvone & 1678 & 0.3 & - \\
\hline 60 & n-Hexadecanoic acid & 1691 & 0.2 & - \\
\hline \multirow[t]{2}{*}{61} & Tricosane & 1903 & 0.1 & - \\
\hline & Total & & 81.6 & 85.6 \\
\hline
\end{tabular}

$150^{\circ} \mathrm{C}$ at a rate of $10^{\circ} \mathrm{C} / \mathrm{min}$ and then kept constant at $150^{\circ} \mathrm{C}$ for $15 \mathrm{~min}$ to $240^{\circ} \mathrm{C}$ at a rate of $5^{\circ} \mathrm{C} / \mathrm{min}$. Alkanes were used as reference points in the calculation of relative retention indices (RRI). MS were taken at $70 \mathrm{eV}$ and a mass range of 35-425. Component identification was carried out using spectrometric electronic libraries (WILEY, NIST).

\section{RESULTS AND DISCUSSION}

The compositions of the oils isolated from two species of Hypericum are reproduced in Table 1. The oils were complex mixtures of nonterpenes, monoterpenes and sesquiterpenes: 62 components were identified in two essential oils under study. Both oils were characterised by a high content of sesquiterpenes. The essential oil analysis showed that sesquiterpenes concentrations were higher than those of monoterpenes. Similarly essential oil compositions of five Hypericum species (Hypericum caprifoliatum Cham. \& Schlecht., Hypericum 
ternum A. St. Hil., Hypericum carinatum Griseb., Hypericum polyanthemum Klotzsch ex Reichardt and Hypericum myrianthum Cham. \& Schlecht.) from southern Brazil showed that sesquiterpenes are present in higher concentrations [17].

A total of forty components of $H$. lanuginosum var. lanuginosum were identified, representing $81.6 \%$ of the total oil. It is observed that spathulenol (17.3\%), caryophyllene oxide $(13.1 \%)$, $\alpha$-pinene $(11.7 \%)$ and undecane $(6.2 \%)$ are the most predominant of the forty compounds. The first major compound of $H$. lanuginosum var. lanuginosum is spathulenol, which is a major constituent of many Hypericum species like, $\mathrm{H}$. perforatum, $H$. maculatum and $H$. olypicum [18], $H$. carinatum [17], $H$. capitatum var. capitatum and var. luteum [8], $H$. thymbrifolium and $H$. pseudolaeve [6], H. avicularifolium subsp. depilatum var. depilatum [9].

Forty components of $H$. perforatum were identified, representing $85.6 \%$ of the total oil. The most abundant constituents were $\beta$-selinene (19.4\%), bicyclogermacrene (15.3\%), 2 tetradecene (8.2\%) and $\alpha$-amorphene (8.1\%). Comparison of the composition of the $H$. perforatum essential oil with literature data on the essential oil of other $H$. perforatum origins showed that the first major component was $\alpha$-pinene, [14-16] except in one report from Yugoslavia, where the main constituent was (E)-caryophyllene (14.2\%) $[18,19]$. Recent studies have pointed out caryophyllene and caryophyllene oxide to be the principal constituents of $H$. perforatum essential oil collected in South-East France [20] and Serbia [19]. Therefore, a large variability in the essential oil composition of $H$. perforatum due to the origin of plant material has to be considered.

Spathulenol, $\alpha$-amorphene, germacerene D, naphthalene, bicyclo $(4,4,0)$ dec-lene and $\alpha$-cadinol were found as main constituents in both oils. The major components caryophyllene oxide, caryophyllene-II, salvial-4(14)-en-1-one and pentacosane, determined in the essential oils of $H$. lanuginosum var. lanuginosum, were not determined in the essential oils of $H$. perforatum (Table 1).
In conclusion, this study demonstrates the occurrence of spathulenol/caryophyllene oxide chemotype of $H$. lanuginosum var. lanuginosum and $\beta$-selinene/bicyclogermacrene chemotype of H. perforatum in Turkey. All studies of this genus, variations in the typical essential oil constituents are related to plant organ, genetic, enviromental and seasonal factors.

\section{References}

1. P.H. Davis, Flora of Turkey and the East Aegean Islands Vol. 2, University Press, Edinburgh, pp. (1967) 355-401.

2. J. Greeson, B. Sanford, D.A. Monti, St. John's wort (Hypericum perforatum L.): a review of the current pharmacological, toxicological and clinical literature, Psychopharmacology, 153 (2001) 402-414.

3. G.M. Kitanov, Hypericin and pseudohypericin in some Hypericum species, Biochemical Systematics and Ecology, 29 (2001) 171-178.

4. N. Tanaka, Y. Takaishi, Xanthones from Hypericum chinense, Phytochemistry, 67 (2006) 2146-2151.

5. E. Bagci, E. Yuce, The Essential Oils of the Aerial Parts of Hypericum apricum Kar. \& Kir. and Hypericum davisii Robson (Guttiferae) Species from Turkey, Journal of Asian Chemistry, 22 (2010) 7405-7409.

6. E. Bagci, E. Yuce, The essential oils of the aerial parts of two Hypericum pseudolaeve Robson and $H$. thymbrifolium Boiss. \& Noe species from East Anatolian region of Turkey, Journal of Essential Oil Bearing Plants, 13 (2010) 390-397.

7. E. Bagci, E. Yuce, Composition of the Essential Oil of Hypericum salsolifolium Hand. Mazz. and Hypericum retusum Aucher, Acta Botanica Gallica, 158 (2011) 169-173.

8. E. Bagci, E. Yuce, Constituents of the essential oils of two varieties of Hypericum capitatum (var. capitatum and var. luteum) varieties from Turkey, Journal of Essential Oil Bearing Plants, 14 (2011) 106-113.

9. E. Yuce, E. Bagci, The essential oils of the aerial parts of two Hypericum taxa (Hypericum triquetrifolium and Hypericum aviculariifolium subsp. depilatum var. depilatum (Clusiaceae)) from Turkey. Natural Product Research, (2012) 1-6.

10. M. Couladis, P. Baziou, P.V. Petrakis, C. Harvala, Essential oil composition of Hypericum perfoliatum L. growing in different locations in Greece, Flavour Fragrance Journal, 16 (2001) 204-206.

11. A. Bertoli, F. Menichini, M. Mazzetti, G. Spinelli, I. Morelli, Volatile constituents of the leaves and flowers of Hypericum triquetrifolium Turra, Flavour Fragrance Journal, 18 (2003) 91-94.

12. T. Nogueira, M.J. Marcelo-Curto, A. Cristina Figueiredo, J.G. Barroso, L.G. Pedro, P. Rubiolo, C. Bicchi, Chemotaxonomy of Hypericum genus from Portugal: Geographical distribution and essential oils composition of Hypericum perfoliatum, Hypericum humifusum, Hypericum linarifolium and Hypericum pulchrum, Biochemical Systematics and Ecology, 36 (2008) 40-50. 
13. L.C. Sara, Essential Oil and Volatile Components of the Genus Hypericum (Hypericaceae), Natural Product Communacations, 5 (2010) 1493-1506.

14. P. Weyerstahl, U. Splittgerber, H. Marschall, Constituents of the leaf essential oil of Hypericum perforatum L. From India, Flavour Fragrance Journal, 10 (1995) 365-370.

15. A. Cakir, M.E. Duru, M. Harmandar, R. Ciriminna, S. Passannanti, F. Piozzi, Comparison of the volatile oils of Hypericum scabrum L. and Hypericum perforatum in Turkey, Flavour Fragrance Journal, 12 (1997), 285.

16. M. Pavlovic, O. Tzakou, P.V. Petrakis, M. Couladis, The essential oil of Hypericum perforatum L., Hypericum tetrapterum Fries and Hypericum olympicum L. growing in Greece, Flavour and Fragrance Journal, 21 (2006) 84-87.
17. A.B.F. Ferraz, R.P. Limberger, S.A.L. Bordignon, G.L. von Poser, A.T. Henriques, Essential oil composition of six Hypericum species from southern Brazil, Flavour Fragrance Journal, 20 (2005) 335-339.

18. A. Smelcerovic, M. Spiteller, A.P. Ligon, Z. Smelcerovic, N. Raabe, Essential oil composition of Hypericum L. species from Southeastern Serbia and their chemotaxonomy, Flavour and Fragrance Journal, 35 (2007) 113.

19. A. Gudzic, S. Dordevic, R. Palic, G. Stojanovic, Essential oils of Hypericum olympicum L. and $H$. perforatum L, Flavour and Fragrance Journal, 16 (2001) 201-203.

20. Schwob, J.M. Bessiere, V. Masotti, J. Viano, Changes in essential oil composition in Saint John's Wort (Hypericum perforatum L.) aerial parts during its Phenological Cycle, Flavour and Fragrance Journal, 32 (2004) 735-745. 